\title{
Performance of Local Clay-Titanium Dioxide Core-Shell Extender Pigments in Alkyd Paints
}

\author{
C. M. Ewulonu ${ }^{1}{ }^{*}$, I. O. Igwe' ${ }^{2}$, G. N. Onyeagoro' ${ }^{2}$ \\ ${ }^{1}$ Department of Polymer and Textile Engineering, Nnamdi Azikiwe University, Awka, Nigeria \\ ${ }^{2}$ Department of Polymer and Textile Engineering, Federal University of Technology, Owerri, Nigeria \\ Email: "cm.ewulonu@unizik.edu.ng
}

Received 13 January 2016; accepted 15 February 2016; published 18 February 2016

Copyright (C 2016 by authors and Scientific Research Publishing Inc.

This work is licensed under the Creative Commons Attribution International License (CC BY). http://creativecommons.org/licenses/by/4.0/

(c) (i)

\begin{abstract}
The performance of local clay-titanium dioxide core-shell extender pigments in alkyd paints has been studied. The physico-mechanical properties of the prepared alkyd paints were evaluated according to ASTM measurements. The effects of various environmental and corrosive factors on the paints were also studied. The study showed that the alkyd paint samples formulated using the core-shell pigments generally had low specific gravity $(1.30-1.38)$, an indication that more of the core-shell pigments can be incorporated into the alkyd paints with considerable cost savings. The dry film thicknesses of the paint samples falls within $0.24-0.39 \mathrm{~mm}$, suggesting that the samples will perform well as anticorrosive coatings and their adhesion properties are generally good, showing that they can withstand abrasive and corrosive agents. The core-shell extender pigments formulated paint samples were observed to exhibit the best dust-free, tack-free, and through dry times compared to $\mathrm{TiO}_{2}$ paint formulation. The formulated paint samples generally performed well on exposure to rain and sunlight as well as in distilled water, $2 \% \mathrm{Na}_{2} \mathrm{CO}_{3}$, and $2 \% \mathrm{H}_{2} \mathrm{SO}_{4}$ with only $\mathrm{TiO}_{2}$ paint formulation exhibiting rust. The good paint performance characteristics obtainable with the core-shell extender pigments are enough evidence to justify their utilization in the surface coatings industry. The performances of these core-shell extender pigments in alkyd paints have shown that they combine the properties of both the clays and titanium dioxide, and have the potential to overcome their disadvantages.
\end{abstract}

\section{Keywords}

Clay, Titanium Dioxide, Extender Pigments, Nanoparticles, Core-Shell Pigments, Alkyd Paints

\footnotetext{
${ }^{*}$ Corresponding author.
}

How to cite this paper: Ewulonu, C.M., Igwe, I.O. and Onyeagoro, G.N. (2016) Performance of Local Clay-Titanium Dioxide Core-Shell Extender Pigments in Alkyd Paints. Advances in Nanoparticles, 5, 90-102. 


\section{Introduction}

Extenders, which are sometimes referred to as extender pigments are an integral part of almost all coating formulations. Talc, mica, kaolin, and feldspar are widely used in coatings as extender pigments and they contribute significantly towards modifying various coating properties such as flow characteristics, settling tendency, abrasion resistance, etc. The pigment that is extended is titanium dioxide $\left(\mathrm{TiO}_{2}\right)$ which is a prime pigment widely used in coatings. These extenders separate the individual $\mathrm{TiO}_{2}$ particles to enhance its opacifying effect.

Pigment extenders are also used to reduce the amount of relatively expensive $\mathrm{TiO}_{2}$ required for a given level of opacification and whiteness. The use of extenders in coatings has the profound disadvantage of low hiding power while titanium dioxide is a photochemically active compound. $\mathrm{TiO}_{2}$ not only contributes to the high cost of coating products, but also increases the rate of degradation of surface coatings [1]. Thus, paint formulators and technologists have begun to find technically and economically viable extenders for use in coatings, in order to bring down the cost of coatings to acceptable limit.

The use of functional fillers/extenders like core-shell extender pigments has shown promising prospects in the paint industry. The core-shell theory is a new way of obtaining high performance, and eco-friendly extender pigments that are cost-effective. In this theory, a cheap extender being the core is covered by a surface layer of very efficient and expensive pigment- the shell [2]. Core-shell particles are examples of nanostructured materials with functional properties such as composite materials where the morphology, microstructure and chemical composition are controlled to achieve various functional properties [3]. Synthesis of various kinds of core-shell particles were reported several decades ago [4]. The composite particles having silica core and titania shell are typically synthesized using techniques like layer-by-layer deposition [5]-[8], sol-gel synthesis [9]-[14], laser pyrolysis [15], heterocoagulation [16] and flame synthesis [17]. Most of these methods are difficult to replicate in commercial quantity because of the multiple steps, $\mathrm{pH}$ control, ingredients like surfactant polyelectrolytes and cutting-edge technologies required [3]. Many literature sources have revealed excellent report on the preparation of core-shell extender pigments [2] [18].

Ahmed and Selim [19] prepared new pigments by depositing a surface layer of an expensive ferrite anticorrosive pigment on a cheap kaolin extender. Paints prepared using the new hybrid pigments offered excellent corrosion protection to steel substrates. Similarly, a new pigment based on the solid-solid interaction of cobalt oxide with zinc oxide on surface of kaolin was prepared by Ahmed et al. [20]. They found that medium oil alkyd-based paints containing the pigments with higher concentration of zinc were best in protecting steel substrates. Ahmed and Selim [21] also prepared kaolin-phosphate (core-shell) pigments based on Egyptian kaolin ore and incorporated the pigments in medium oil alkyd resin. Their results showed that the pigments could successfully replace phosphate pigments with improved corrosion protection of the substrates tested.

In order to mitigate $\mathrm{TiO}_{2}$ deficiency in coatings, and optimize paint formulations for the best cost-performance, the present study demonstrated the performance of a simple synthesized new extender pigment system using Nigerian local clay as core and titanium dioxide as shell in alkyd paints.

\section{Materials and Methods}

\subsection{Materials}

The local clays used were sourced from two different locations, Obowo and Ihitte-Uboma Local Government Areas within the South-Eastern region of Nigeria. Analytical grade of titanium tetrachloride $\left(\mathrm{TiCl}_{4}\right)$, hydrochloric acid and ammonia solution from BDH Laboratory were used. The core-shell extender pigments were prepared using local clays of $0.150 \mathrm{~mm}$ particle size which was found to be the major size present in both clays.

\subsection{Preparation of Core-Shell Extender Pigments [22]}

Titanium tetrachloride $\left(\mathrm{TiCl}_{4}\right)$ was added in three different concentrations of 2, 4, and $6 \mathrm{~cm} 3$ to $100 \mathrm{~cm}^{3}$ hydrochloric ( $\mathrm{HCl}$ ) acid contained in three different $500 \mathrm{~cm}^{3}$ beakers. The Obowo or Ihitte-Uboma clay was then immersed in the three different solutions respectively, was gradually stirred and allowed for some time for the clay to settle, while the $\mathrm{HCl}$ formed an envelope on top of the settled clay. Ammonia solution was added to the impregnated clays in drops to adjust their $\mathrm{pH}$ till the extender pigments are completely precipitated. The paste formed was filtered through a Buchner funnel and washed with distilled water, dried, and calcined at $650^{\circ} \mathrm{C}$. Three different concentrations of titanium dioxide, and consequently, of titanium, was expected to be deposited 
on the clay surface.

\subsection{Preparation of the Core-Shell Extender Pigmented Alkyd Paints}

Alkyd paint samples were prepared using the prepared core-shell extender pigments and $\mathrm{TiO}_{2}$. Paints prepared using $\mathrm{TiO}_{2}$ were for reference purpose. Xylene was used as the solvent while a medium oil alkyd resin based on soya bean oil purchased from TonyKelv Nigeria Ltd., Onitsha, Nigeria was used in this study as the binder. The different alkyd paint formulations studied are shown in Table 1. Lead and Cobalt naphthanate with metal contents of $36 \% \mathrm{~Pb}$ and $12 \%$ Co were used as driers. Cobalt naphthanate was used for surface dry, while lead naphthanate drier was used for through dry.

\subsection{Preparation of Paint-Drier Mixtures}

A given quantity of the prepared paint sample was accurately weighed, and calculated amounts of lead napthanate and cobalt naphthanate driers were added. The paint-drier mixture was mixed thoroughly using a glass rod. The amount of driers added represents $0.50 \mathrm{wt} \%$ lead $(\mathrm{Pb})$, and $0.05 \mathrm{wt} \%$ cobalt $(\mathrm{Co})$ which are the amount of these metals normally used in the surface coatings industry [23]. The amount of driers giving the above percentage of metals in the paint-drier mixtures was calculated as follows:

$$
\text { Amount of drier required }=\frac{\text { Weight of resin in paint } \times \% \text { of metal required }}{\% \text { of metal in drier }}
$$

\subsection{Property Determination on Prepared Alkyd Paint Samples}

The American standard testing methods (ASTM) was used to evaluate the prepared alkyd paint samples for viscosity (ASTM D 1200-10), specific gravity (ASTM D 1475-13), adherence to surface (ASTM D 6677-07, 2012), settling and skinning tendencies (ASTM D 869-85). The settling tendencies of the samples were rated in accordance to the degree of settling on a scale that range from 10 to 0 (Table 2). Intermediate conditions were given appropriate odd numbers. The Nigerian Industrial Standard (NIS) procedure was used to study the mildew formation resistance (NIS 278:1990), media resistance and chalking tendency (NIS 268:1989) of the prepared alkyd paint samples. Mild steel panels were used as the coating surfaces for the casting of paint-drier mixtures. The panels were prepared according to ASTM D 609-00 procedure, and were taped to $0.40 \mathrm{~mm}$ thickness for the casting of the paint-drier mixtures. The paint-drier wet film thickness was assumed the same as the thickness of the tape layer used. The paint-drier mixtures were cast immediately after their preparations on the taped-off portions of the mild steel panels; the wet paint-drier films were leveled off using a short glass rod. The coated plates were placed on a level surface and were allowed to dry at room temperature. Subsequently, the drying properties (surface (dust-free) dry, tack free dry and through dry) were studied.

Table 1. Alkyd paint formulations with $\mathrm{TiO}_{2}$, and core-shell extender pigments.

\begin{tabular}{|c|c|c|c|c|c|c|c|}
\hline \multirow{3}{*}{ Ingredients } & \multicolumn{7}{|c|}{ Formulations (wt\%) } \\
\hline & \multirow{2}{*}{$\begin{array}{c}\mathrm{TiO}_{2} \\
\text { Commercial Kronox } \\
\text { Titanium Dioxide }\end{array}$} & OBC-TC2 & OBC-TC4 & OBC-TC6 & IHC-TC2 & IHC-TC4 & IHC-TC6 \\
\hline & & \multicolumn{3}{|c|}{$\begin{array}{l}\text { Core-Shell Extender Pigments from } \\
\text { Obowo Clay Formulations }\end{array}$} & \multicolumn{3}{|c|}{$\begin{array}{l}\text { Core-Shell Extender Pigments from } \\
\text { Ihitte-Uboma Clay Formulations }\end{array}$} \\
\hline Alkyd resin & 37 & 37 & 37 & 37 & 37 & 37 & 37 \\
\hline $\mathrm{TiO}_{2}$ & 63 & - & - & - & - & - & - \\
\hline $\mathrm{TiO}_{2} / \mathrm{LCC}(2)$ & - & 63 & - & - & 63 & - & - \\
\hline $\mathrm{TiO}_{2} / \mathrm{LCC}(4)$ & - & & 63 & - & - & 63 & - \\
\hline $\mathrm{TiO}_{2} / \mathrm{LCC}(6)$ & - & - & - & 63 & - & - & 63 \\
\hline Total & 100 & 100 & 100 & 100 & 100 & 100 & 100 \\
\hline $\mathrm{P} / \mathrm{B}$ ratio & 1.7 & 1.7 & 1.7 & 1.7 & 1.7 & 1.7 & 1.7 \\
\hline Solvent & 12 & 12 & 12 & 12 & 12 & 12 & 12 \\
\hline
\end{tabular}

Note: $\mathrm{TiO}_{2} / \mathrm{LCC}(2), \mathrm{TiO}_{2} / \mathrm{LCC}(4)$, and $\mathrm{TiO}_{2} / \mathrm{LCC}$ (6) are the three different core-shell extender pigments prepared for each local clay that contain 2, 4 , and $6 \mathrm{~cm}^{3}$ of titanium tetrachloride. 
Table 2. Ratings on degree of settling of paint samples.

\begin{tabular}{cl}
\hline Rating & Description of Paint Conditions \\
\hline $\mathbf{1 0}$ & Perfect suspension, no changes from original condition of paint. \\
$\mathbf{8}$ & A definite feel of settling and a slight deposit brought on spatula. \\
$\mathbf{6}$ & Definite cake of settled pigments, spatula drops through cake to bottom of the container under its own weight. \\
$\mathbf{4}$ & $\begin{array}{l}\text { Spatula does not fall to bottom of container under its own weight. Difficult to move spatula through cake sidewise and } \\
\text { slight edge resistance. }\end{array}$ \\
$\mathbf{0}$ & Definite edgewise resistance to movement of spatula. \\
\hline
\end{tabular}

\section{Results and Discussions}

\subsection{Properties of the Prepared Core-Shell Extender Pigments}

The X-ray fluorescence (XRF) determinations on the core-shell extender pigments presented in Table 3 shows that two major constituents of the prepared extender pigments in order of abundance are silica, $\left(\mathrm{SiO}_{2}\right)$ and aluminum oxide $\left(\mathrm{Al}_{2} \mathrm{O}_{3}\right)$. The titanium dioxide $\left(\mathrm{TiO}_{2}\right)$ content of the core-shell extender pigments are between 7.0 and 13.0 wt\% while Weaver [24] reported that $\mathrm{TiO}_{2}$ values in kaolin commonly range from $0.20 \%$ to $2.50 \%$. The high $\mathrm{TiO}_{2}$ content in the prepared core-shell extender pigments is an indication of the presence of titanium dioxide and consequently titanium deposited on the clays.

The particle morphology of the core-shell pigments obtained from scanning electron microscope (SEM) shown in Figure 1 and Figure 2 indicates that the Obowo and Ihitte-Uboma core-shell extender pigments are nodular (a rounded irregular shape) shaped structures of different sizes. It can be inferred that as titanium is deposited on the clay surfaces, new structures are formed which have the clays appearing as clouds in the background of the micrographs and this may be attributed to the purity and fine particle nature of the clays. Therefore, the combination of the clay and titanium dioxide structure possibly lead to the formation of core-shell structures of different plate sizes without any change in the plate shapes.

The properties of the core-shell extender pigments presented in Table 4 shows that the prepared extender pigments are slightly alkaline having values ranging from $7.45-7.56$. It is important to note that the $\mathrm{pH}$ of the prepared core-shell extender pigments were not much affected by progressive increase in titanium dioxide deposited on the pigments. The specific gravity of the core-shell extender pigments were found to increase with increase in titanium dioxide present in the pigments. From the present study, the core-shell extender pigments have lower specific gravity than titanium dioxide. Interestingly, lower specific gravity of pigments leads to a considerable cost saving in coatings [25].

The refractive indices of the prepared core-shell pigments determined using an Abbe's refractometer also presented in Table 4 illustrates that the pigments have refractive index lower than that of $\mathrm{TiO}_{2}$ pigment but higher than other extenders. It is important to note that all extenders have refractive index that fall in the range between, 1.45 and 1.65 [26]. Therefore, the core-shell extender pigments have shown a remarkable improvement in the refractive index of extenders and can be considered to impart opacity to polymer coatings. The refractive indices of the prepared core-shell extender pigments were found to increase with increase in titanium dioxide deposited on the extender pigments.

The core-shell extender pigments' oil absorption properties were determined using the spatula rub-out technique and results obtained are shown in Table 4. The various prepared core-shell extender pigments exhibited roughly the same oil absorption values, and which is higher than the oil absorption $\mathrm{TiO}_{2}$ pigment. Less oil absorption indicates less resin demand without compromising other coating properties [27]. The oil absorption depends mainly on the physical structure (i.e. size and shape of the extender particles), which also affects several other coating properties including flow characteristics, setting tendency, film durability [28].

\subsection{Specific Gravity}

The specific gravity values of core-shell extender pigments and titanium dioxide $\left(\mathrm{TiO}_{2}\right)$ formulated alkyd paints are shown in Table 5 and illustrated graphically in Figure 3. The table shows that the $\mathrm{TiO}_{2}$ formulated alkyd paint has the highest specific gravity when compared to those formulated using the core-shell pigments. This is 
Table 3. XRF analysis results of the prepared core-shell extender pigments.

\begin{tabular}{|c|c|c|c|c|c|c|}
\hline Constituents (wt\%) & OBC-ТC2 & OBC-TC4 & ОВС-ТС6 & IHC-TC2 & IHC-TC4 & IHC-TC6 \\
\hline $\mathrm{SiO}_{2}$ & 66.7 & 66.8 & 65.8 & 54.64 & 52.7 & 52.78 \\
\hline $\mathrm{Al}_{2} \mathrm{O}_{3}$ & 19.8 & 17.3 & 17 & 27.83 & 25.7 & 25.56 \\
\hline $\mathrm{TiO}_{2}$ & 7.22 & 9.94 & 11.3 & 7.18 & 10.8 & 12.54 \\
\hline $\mathrm{K}_{2} \mathrm{O}$ & 0.67 & 0.453 & 0.4 & 0.72 & 0.712 & 0.771 \\
\hline $\mathrm{CaO}$ & 0.3 & 0.298 & 0.231 & 0.85 & 0.611 & 0.647 \\
\hline $\mathrm{Fe}_{2} \mathrm{O}_{3}$ & 2.12 & 2.1 & 2.13 & 4.63 & 4.84 & 3.97 \\
\hline $\mathrm{MgO}$ & 0.15 & 0.143 & 0.14 & 0.17 & 0.18 & 0.161 \\
\hline $\mathrm{Na}_{2} \mathrm{O}$ & 0.382 & 0.291 & 0.338 & 0.11 & 0.12 & 0.13 \\
\hline $\mathrm{V}_{2} \mathrm{O}_{5}$ & 0.15 & 0.16 & 0.16 & 0.192 & 0.32 & 0.18 \\
\hline $\mathrm{Cr}_{2} \mathrm{O}_{3}$ & 0.004 & 0.004 & 0.003 & 0.02 & 0.023 & 0.053 \\
\hline $\mathrm{Ga}_{2} \mathrm{O}_{3}$ & 0 & 0 & 0 & 0.02 & 0.031 & 0.02 \\
\hline $\mathrm{MnO}$ & 0.02 & 0.024 & 0.021 & 0.01 & 0.01 & 0.02 \\
\hline $\mathrm{Sc}_{2} \mathrm{O}_{3}$ & 0 & 0 & 0 & 0.001 & 0.001 & 0.001 \\
\hline $\mathrm{CuO}$ & 0.015 & 0.016 & 0.014 & 0.02 & 0.015 & 0.028 \\
\hline $\mathrm{ZnO}$ & 0 & 0 & 0 & 0.008 & 0 & 0 \\
\hline $\mathrm{Bi}_{2} \mathrm{O}_{3}$ & 0 & 0 & 0 & 0 & 0 & 0 \\
\hline L.O.I & 2.4 & 2.4 & 2.41 & 3.58 & 3.86 & 3.12 \\
\hline Total & 99.931 & 99.929 & 99.947 & 99.981 & 99.923 & 99.981 \\
\hline
\end{tabular}

Abbreviations: $\mathrm{OBC}=$ Obowo clay core-shell pigment; TC = Titanium tetrachloride; IHC = Ihitte-uboma core-shell pigment; 2, 4, $6=$ Quantity $\left(\mathrm{cm}^{3}\right)$ of $\mathrm{TC}$ in OBC or IHC.

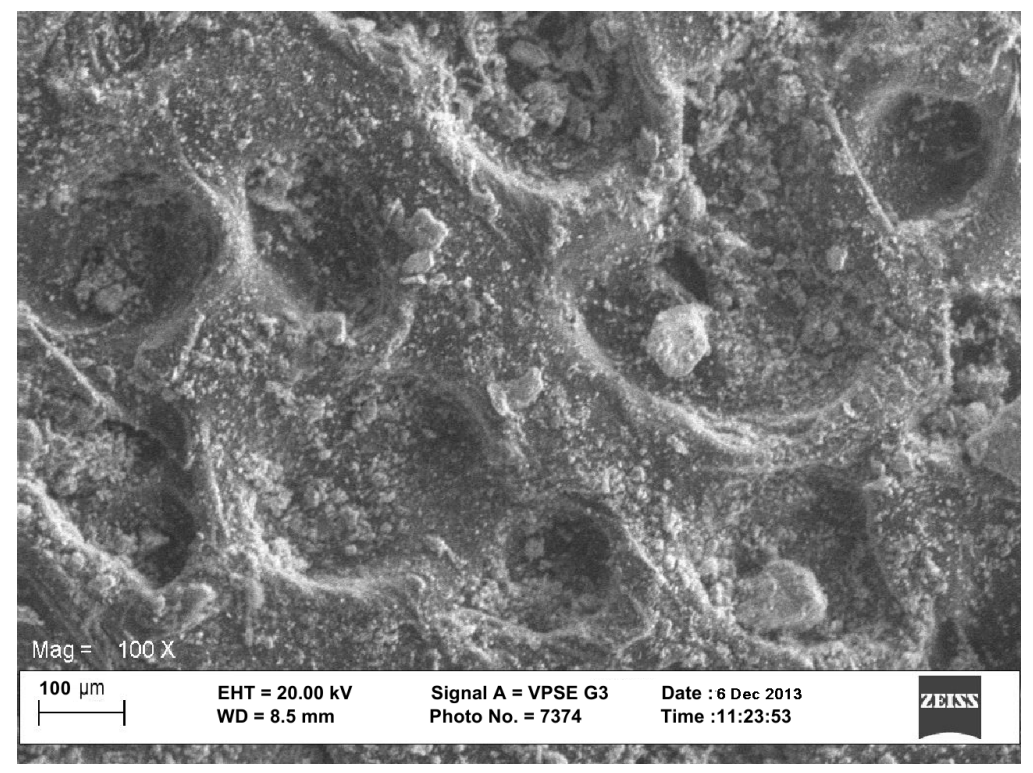

Figure 1. SEM micrograph of IHITTE-UBOMA core-shell pigment.

to be expected since $\mathrm{TiO}_{2}$ pigment has the highest specific gravity value compared to the core-shell pigments used in this study [22]. The alkyd paints formulated using the core-shell pigments exhibited low values of specific gravity. Obviously, more of the core-shell pigments can be incorporated into the alkyd paints with considerable cost saving when compared to the incorporation of $\mathrm{TiO}_{2}$ in alkyd paint. Specific gravity of paints is used to determine the coverage of paint products on a substrate, that is, the volume occupied by a known weight of paint product [29]. 


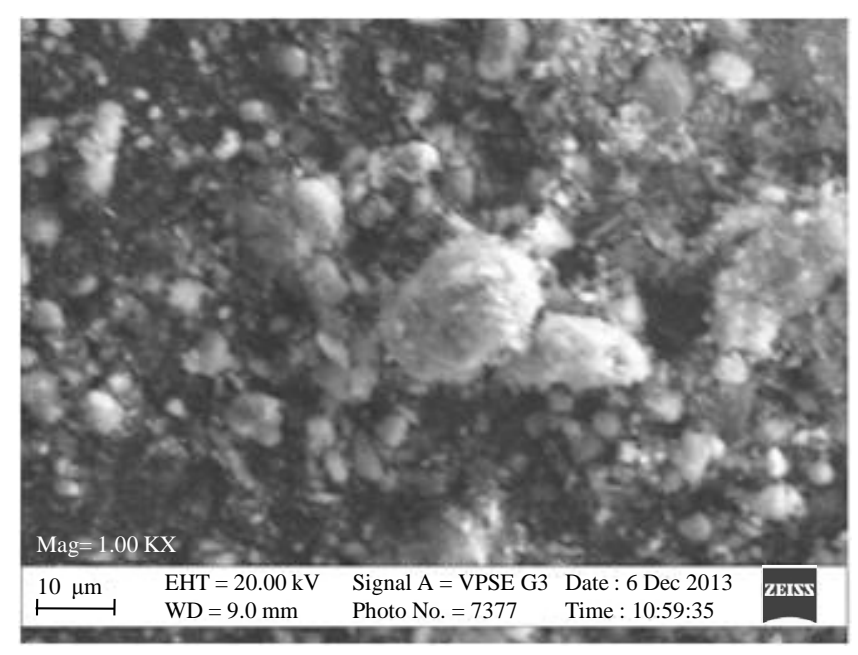

Figure 2. SEM micrograph of Obowo core-shell pigment.

Table 4. Properties of the core-shell extender pigments.

\begin{tabular}{ccccc}
\hline Sample & $\mathbf{p H}$ & Specific Gravity $\mathbf{g} / \mathbf{c m}^{\mathbf{3}}$ & Refractive Index & Oil Absorption $\mathbf{g} / \mathbf{1 0 0 g}$ \\
\hline KRONOS 2190 $\mathrm{TiO}_{2}$ & $7.5-8.0$ & 4.1 & 2.55 & 18 \\
OBC-TC2 & 7.56 & 2.87 & 1.88 & 25 \\
OBC-TC4 & 7.55 & 3.05 & 1.93 & 25 \\
OBC-TC6 & 7.56 & 3.08 & 1.96 & 24 \\
IHC-TC2 & 7.45 & 2.92 & 1.91 & 24 \\
IHC-TC4 & 7.46 & 3.07 & 1.93 & 25 \\
IHC-TC6 & 7.46 & 3.10 & 1.95 & 25 \\
\hline
\end{tabular}

Table 5. Coating properties of prepared core-shell extender pigmented paints.

\begin{tabular}{|c|c|c|c|c|c|c|c|c|}
\hline \multirow{2}{*}{$\begin{array}{c}\text { Formulation } \\
\text { Code }\end{array}$} & \multirow{2}{*}{$\begin{array}{l}\text { Specific } \\
\text { Gravity }\end{array}$} & \multirow{2}{*}{$\begin{array}{l}\text { Viscosity } \\
\text { (poise) }\end{array}$} & \multirow{2}{*}{$\begin{array}{c}\text { Dry Film } \\
\text { Thickness } \\
\text { (mm) }\end{array}$} & \multicolumn{3}{|c|}{ Drying Time (Min) } & \multirow{2}{*}{$\begin{array}{c}\text { Settling } \\
\text { Test }\end{array}$} & \multirow{2}{*}{$\begin{array}{c}\text { Adherence } \\
\text { Test (\%) }\end{array}$} \\
\hline & & & & $\begin{array}{l}\text { Dust } \\
\text { Free }\end{array}$ & Tack Free & $\begin{array}{c}\text { Through } \\
\text { Dry }\end{array}$ & & \\
\hline $\mathrm{TiO}_{2}$ & 1.55 & 16.61 & 0.24 & 71 & 99 & 150 & 9 & 4 \\
\hline OBC-TC2 & 1.30 & 58.13 & 0.30 & 30 & 40 & 88 & 6 & 1 \\
\hline OBC-TC4 & 1.35 & 57.53 & 0.27 & 32 & 49 & 88 & 7 & 2 \\
\hline OBC-TC6 & 1.35 & 36.61 & 0.26 & 40 & 58 & 92 & 7 & 8.5 \\
\hline IHC-TC2 & 1.35 & 56.57 & 0.30 & 17 & 28 & 38 & 5 & 1 \\
\hline IHC-TC4 & 1.35 & 54.88 & 0.30 & 19 & 30 & 43 & 5 & 1.5 \\
\hline IHC-TC6 & 1.38 & 34.50 & 0.29 & 22 & 31 & 44 & 6 & 1 \\
\hline
\end{tabular}

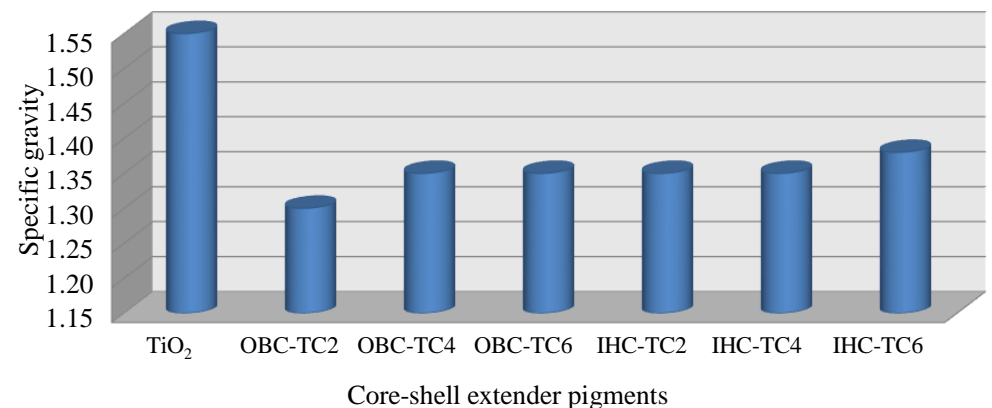

Figure 3. Effect of core-shell extender pigments on the specific gravity of alkyd paint formulations. 
The study shows that alkyd paints formulated using Ihitte-Uboma core-shell extender pigments prepared using $2 \mathrm{~cm}^{3}$, and $4 \mathrm{~cm}^{3}$ of $\mathrm{TiCl}_{4}$, as well as Obowo core-shell extender pigments prepared using $4 \mathrm{~cm}^{3}$ and $6 \mathrm{~cm}^{3}$ $\mathrm{TiCl}_{4}$ exhibited the same specific gravity (1.35) in paints. The alkyd paint formulated using Obowo core-shell pigments that was prepared using $2 \mathrm{~cm}^{3} \mathrm{TiCl}_{4}$ exhibited the least specific gravity in the prepared paints.

\subsection{Viscosity of Alkyd Paint Samples}

The viscosity values of the formulated alkyd paint samples are presented in Table 5 and illustrated graphically in Figure 4. Titanium dioxide $\left(\mathrm{TiO}_{2}\right)$ formulated alkyd paint exhibited the least viscosity value among the alkyd paints studied. The present study has shown that the viscosity of alkyd paints prepared using the core-shell extender pigments was observed to decrease as the quantity of $\mathrm{TiO}_{2}$ they contain increased, and vice-versa. The range of viscosities observed for the paint samples makes them suitable for application by spray or brush. Tiwari and Saxena [26] who studied fly ash extended coatings obtained viscosities that ranged between 2.0 and 2.58 Pa.s, and noted that the formations were suitable for application by brush or spray. The interaction of various constituents in any coating system determines its viscosity [30]. Viscosity affects the application and flow properties of a coating and is generally adjusted to the intended application [31] [32]. According to the Nigerian Industrial Standard NIS 268:1989, the minimum viscosity for gloss paint shall be 22 centipoise.

\subsection{Dry Paint Film Thickness}

The thickness of a coating is of importance since it profoundly affects the other properties of coatings such as the extent of protection of a substrate by the applied paint. The data obtained on the thickness of the dried paint films in this study are presented in Table 5 and illustrated graphically in Figure 5 . From the figure, it is evident that $\mathrm{TiO}_{2}$ formulated paint exhibited the least paint dry film thickness $(0.24 \mathrm{~mm})$. Though the thickness of the

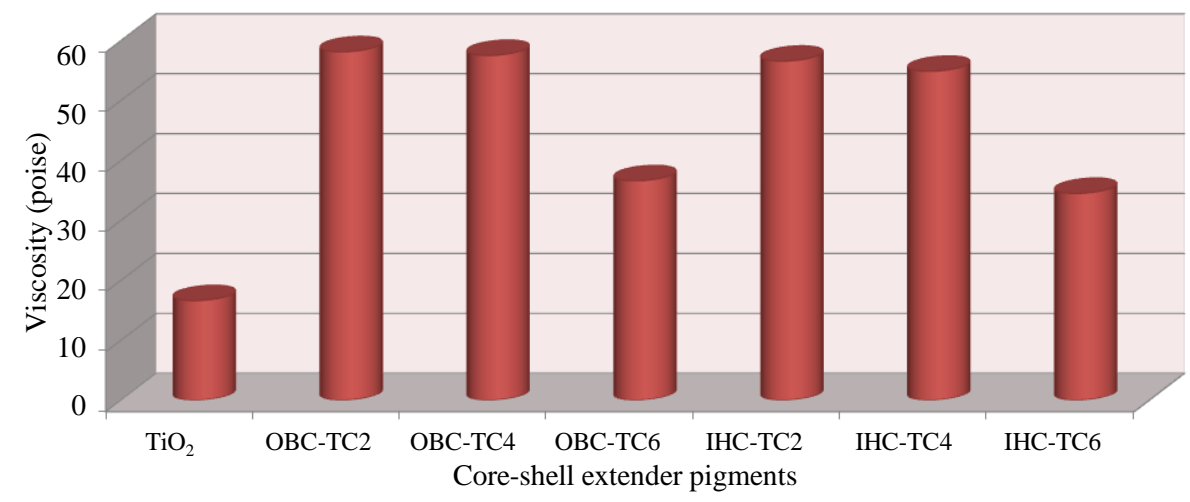

Figure 4. Effect of core-shell extender pigments on the viscosity of alkyd paint formulations.

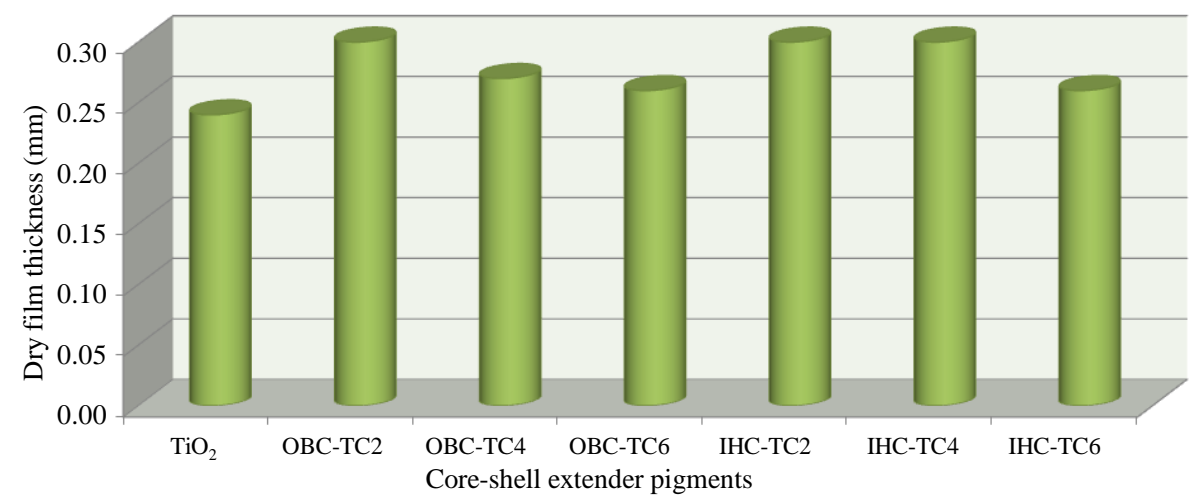

Figure 5. Effect of core-shell extender pigments on the dry film thickness of alkyd paint formulations. 
alkyd paint films formulated using the core-shell extender pigments were generally observed to decrease with increase in $\mathrm{TiO}_{2}$ content, the Ihitte-Uboma core-shell extender pigments formulated paint samples exhibited the highest film thickness.

According Tan Tian Aik, [33], weight loss due to weathering is proportional to film thickness up to $20 \mu \mathrm{m}$, above which the rate of weight loss becomes indifferent of the thickness. Thus, a film thickness of more than 20 $\mu \mathrm{m}$ performs well as a barrier resistant to weathering. The results obtained in this study on the film thickness of the samples studied are in the desired range to be considered for corrosion protection.

\subsection{Drying Studies on Paint Film Samples}

The drying properties of the prepared paint samples given in Table 5 are illustrated graphically in Figure 6. The drying properties investigated are dust-free dry, tack-free dry, and through-dry.

\subsubsection{Dust-Free Dry Times}

The alkyd paint samples formulated using the Ihitte-Uboma core-shell pigments exhibited the best dust-free drying times than Obowo core-shell pigments and $\mathrm{TiO}_{2}$ in the formulated paint samples. The paint samples formulated with Obowo, and Ihitte-Uboma core-shell pigments exhibited good dust-free drying times which were found to increase with increase in the quantity of $\mathrm{TiCl}_{4}$ used in preparing the pigments. It is important to note that the higher the quantity of $\mathrm{TiCl}_{4}$ used in preparing the pigments, the higher the quantity of $\mathrm{TiO}_{2}$ deposited on the extender pigments [22]. In essence, high $\mathrm{TiO}_{2}$ content was observed to increase the dust-free drying times of the formulated alkyd paints; with $\mathrm{TiO}_{2}$ formulated paint having the highest dust-free drying time.

\subsubsection{Tack-Free Dry Times}

An applied paint film is considered tack-free (TF) when the finger with a slight pressure did not leave any mark, and the surface not sticky. The paint sample prepared using $\mathrm{TiO}_{2}$ had the highest tack-free drying time of 99 minutes, while the paint samples of Obowo core-shell pigment formed with $6 \mathrm{~cm}^{3}$ of $\mathrm{TiCl}_{4}$ followed with a tack-free drying time of 58 minutes. Like was noted for the dust-free drying times of the prepared paint samples, the tack-free drying times of the core-shell extender pigments formulated alkyd paints of Obowo, and IhitteUboma clays exhibited drying times that increased with increase in $\mathrm{TiO}_{2}$ incorporated into the clays. The coreshell pigments of Ihitte-Uboma clay prepared using $2 \mathrm{~cm}^{3}$ of $\mathrm{TiCl}_{4}$ exhibited the least drying times in the formulated paint samples. The alkyd paint samples of the core-shell extender pigments were observed to exhibit lower tack-free drying times than $\mathrm{TiO}_{2}$ formulated paint. The tack-free dry times of the formulated alkyd paint samples with core-shell extender pigments are generally good. According to Nigerian Industrial Standard, NIS 268:1989, the surface dry time of gloss paint shall not exceed 6 hours from the time of application.

\subsubsection{Through Dry Times}

The through dry times of the formulated paint samples illustrated in Figure 6 shows that $\mathrm{TiO}_{2}$ formulated paint

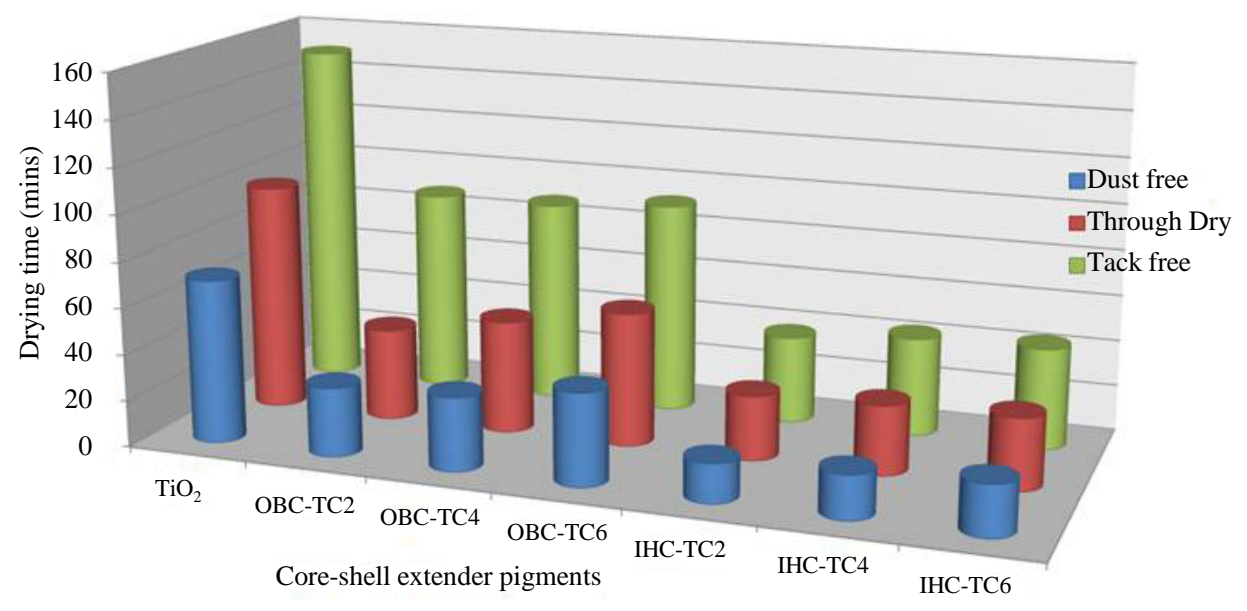

Figure 6. Effect of core-shell extender pigments on the adherence of alkyd paint formulations. 
sample exhibited the highest through dry time (150 minutes). All the core-shell extender pigment formulated alkyd paints of Obowo, and Ihitte-Uboma clays generally had through dry times that increased with increase in $\mathrm{TiO}_{2}$ content. The through dry times of Obowo core-shell extender pigments were generally greater than the through dry times of Ihitte-Uboma core-shell pigments formulated alkyd paints.

Generally, the core-shell extender pigments formulated alkyd paints of Obowo, and Ihitte-Uboma clays exhibited the best dust-free, tack-free, and through dry times when compared to the $\mathrm{TiO}_{2}$ paint formulation. According to the Nigerian Industrial Standard, NIS 268:1989, the through dry time of gloss paint shall not exceed 24 hours.

\subsection{Chalking Test on Paint Film Sample}

The chalking tests carried out on the formulated paint samples indicated that none of the paint samples showed any sign of chalking. A good paint should not chalk. The results of the above test showed that the core-shell extender pigments performed equally well in coatings just like the paint prepared using the conventional $\mathrm{TiO}_{2}$ pigment.

\subsection{Skinning and Settling Tests}

The formulated paint samples exhibited no sign of skin formation after eight months of storage. Various degrees of settling were observed in the samples after eight months of storage as shown in Table 5 and illustrated graphically in Figure 7. The settling tests shows that paints formulated using the core-shell extender pigments from both local clays showed moderate settling tendencies when compared to the formulation containing $\mathrm{TiO}_{2}$ pigment which almost showed no settling tendency. However, the settling tendencies of the core-shell extender pigment formulated alkyd paints were observed to be independent on $\mathrm{TiO}_{2}$ content though at the highest $\mathrm{TiO}_{2}$ content of the core-shell pigments, they showed an improved settling tendency.

Generally, some properties of pigments affect their settling tendencies. These include particle size, particle shape, specific gravity, and the activity which includes such properties as basicity, wettability, flocculating, dispersing and gel forming tendencies. The properties of the binder also influence the settling tendencies. It is probable to reason that the difference in settling tendency observed for the core-shell extender pigments and $\mathrm{TiO}_{2}$ formulated paint samples may be due to the difference in their particle structure.

Furthermore, specific gravity is known to be related to the sedimentation and granulation of paints and affects the rate at which solid particles settle in liquids. The core-shell pigments were reported [22] to have specific gravity that was lower than that of $\mathrm{TiO}_{2}$. The proportional difference between the specific gravities of these extender pigments and the binder may have led to the slight settling noticed in the core-shell extender pigments based paint formulations. Oil absorption of pigments also relates to its settling tendencies. Pigments with high oil absorption will tend to absorb the paint vehicle and form coat after an extended period of storage. $\mathrm{TiO}_{2}$ pigments were reported [22] to have oil absorption value that was lower than those of the core-shell pigments. This could have also contributed to the various levels of settling observed in the paint samples.

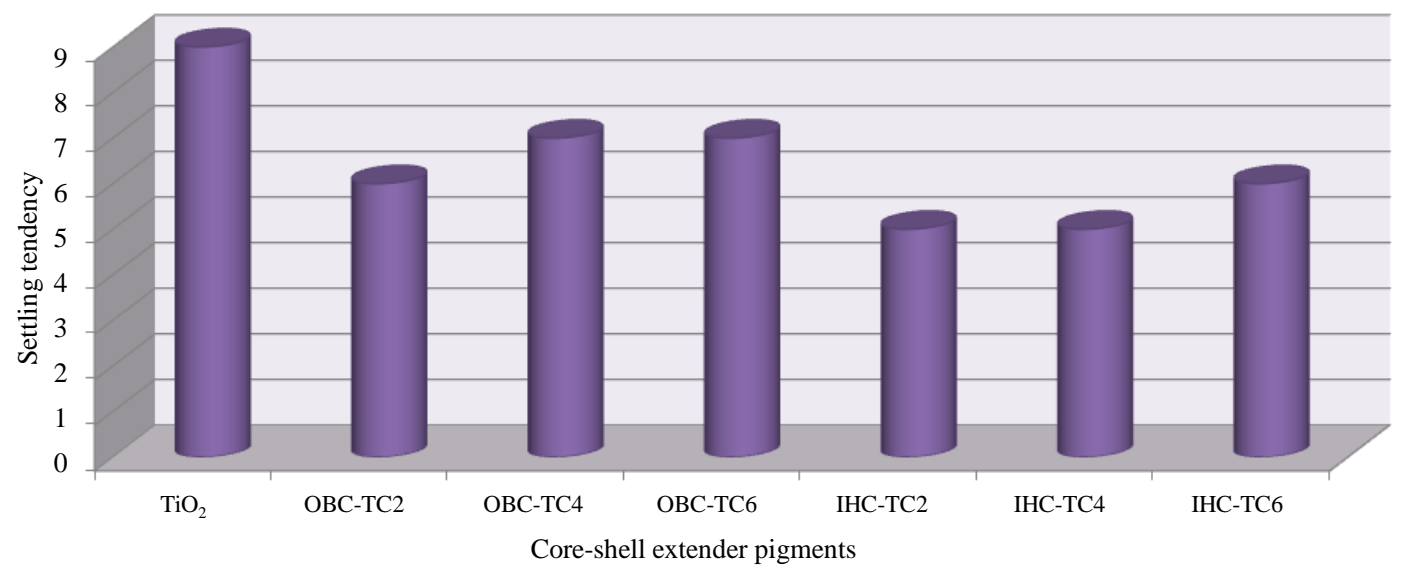

Figure 7. Effect of core-shell extender pigments on the settling tendency of alkyd paint formulations. 


\subsection{Adherence to Surface of Paint Films}

Data on the adhesion properties of the prepared paint samples are shown in Table 5, and illustrated graphically in Figure 8. The figure shows that all the alkyd paint samples exhibited good adhesion properties. According to Nigerian Industrial Standard, NIS 268:1989, gloss paint should not exhibit more than 50\% removal of the dried paint film. The paint samples prepared using the core-shell extender pigments of Ihitte-Uboma clay, core-shell extender pigments of Obowo clay (with the exception of the pigment containing $6 \mathrm{~cm}^{3} \mathrm{TiCl}_{4}$ ), exhibited particularly good adhesion properties. For the paint samples formulated using the Obowo core-shell extender pigments, the \% adhesion loss of paint dry film was observed to increase with increase in $\mathrm{TiO}_{2}$ content. Alkyd paints formulated with Obowo clay core-shell extender pigment prepared using $6 \mathrm{~cm}^{3} \mathrm{TiCl}_{4}$ exhibited the highest \% adhesion loss of dry paint film (8.5\%) followed by the $\mathrm{TiO}_{2}$ pigment formulated paint sample. All the prepared paint samples exhibited \% adhesion loss in the range, 1 - 10. Adhesion according to ASTM D 907 (2012) is defined as the state in which two surfaces are held together by interfacial forces which may consist of valence forces or interlocking action or both. For the most part, organic coatings are removed in service by abrasion, chipping, coins, and other instruments, picking away at exposed edges, corrosion of the substrate, impact or impingement by stones, etc.

\subsection{Mildew Formation and Light Fastness of Dry Paint Film Samples}

All the formulated alkyd paint samples did not show any sign of mildew formation after seven months of exposure to rain, and sunlight. This is an indication that the core-shell extender pigments performed equally well in coatings just like the $\mathrm{TiO}_{2}$ formulated paint samples. On the other hand, the alkyd paint formulated samples shaded their color after seven months of exposure to rain and sunlight. The paint formulations containing $\mathrm{TiO}_{2}$ exhibited slight rust while all the core-shell extender pigment based paint formulations resisted rust as shown in Figure 9. This is an indication that the core-shell extender pigment formulations can withstand environmental challenges, and therefore can be used in corrosive environment.

\subsection{Media Resistance Test on Paint Film Samples}

The visual changes that occurred on the formulated paint films after immersion in $2 \% \mathrm{NaCl}, 2 \% \mathrm{H}_{2} \mathrm{SO}_{4}$, and $2 \%$ $\mathrm{Na}_{2} \mathrm{CO}_{3}$ and distilled water for 24 hours are presented in Table 6. The performance of the paint samples shown in Figure 10 were rated according to the method of Muralidharan [34] as follows: 0-No change; 1-Very slight effect; 2-Effect; 3-Light effect; 4-Definite effect; 5—Bad effect.

From Table 6, it is evident that all the formulated paint samples performed satisfactorily in $2 \% \mathrm{Na}_{2} \mathrm{CO}_{3}$ and distilled water with the exception of $\mathrm{TiO}_{2}$ formulated paint sample. The paint samples also performed well in $2 \%$ sulphuric acid. The performance in $2 \% \mathrm{NaCl}$ was good; except for slight salt effect on paint samples formulated using $\mathrm{TiO}_{2}$. The good performance of the core-shell pigments based paints in acidic as well as $2 \% \mathrm{Na}_{2} \mathrm{CO}_{3}$ could be attributed to the presence of inert oxides they contain [22] [26].

It is important to note that water in one way or the other is the common enemy to most materials of construction. The absorption of water by paint films can lead to loss of components from the film, and subsequent deterioration

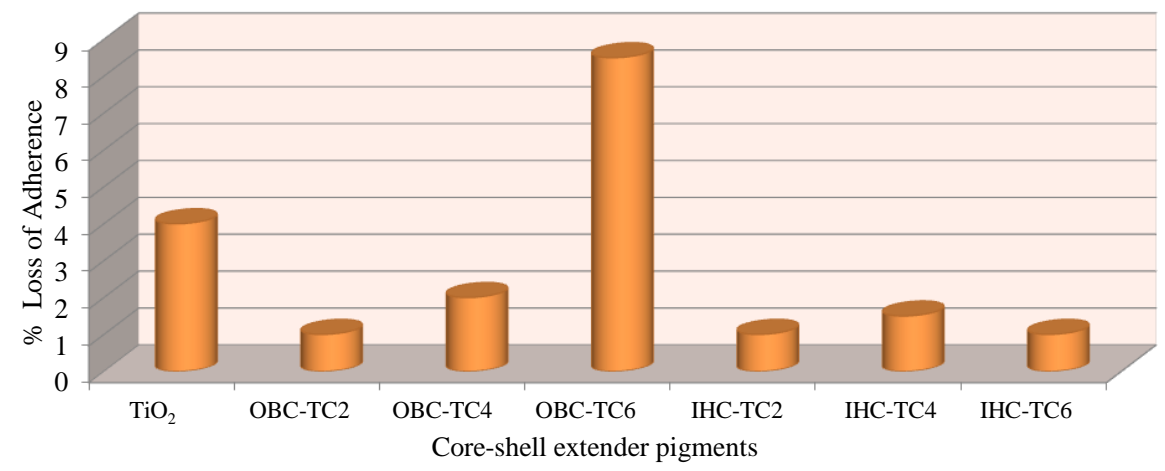

Figure 8. Effect of core-shell extender pigments on the \% loss of adherence of alkyd paint formulations. 


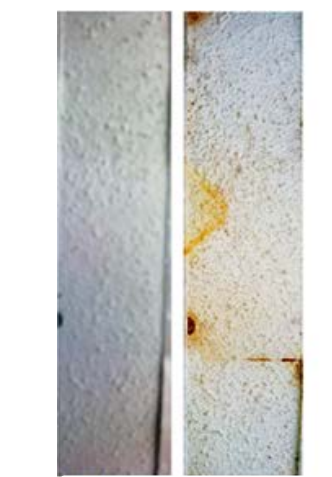

$\mathrm{T}$ :Before and After Exposure

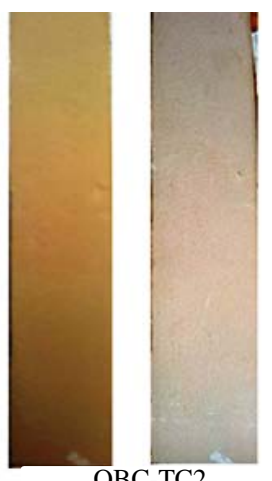

Before and After Exposure

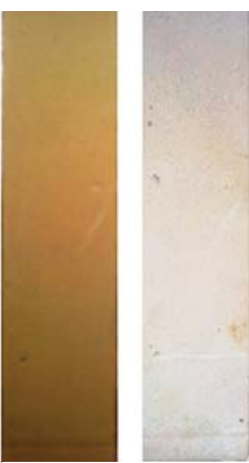

OBC-TC4 Before and After Exposure

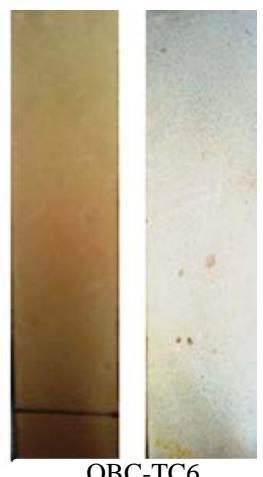

Before and After Exposure

Figure 9. Pictures of environmental tests on paint film samples.

Table 6. Media resistance of prepared paint samples.

\begin{tabular}{ccccc}
\hline Formulation Code & $2 \% \mathrm{NaCl}$ & $2 \% \mathrm{H}_{2} \mathrm{SO}_{4}$ & $2 \% \mathrm{Na}_{2} \mathrm{CO}_{3}$ & 1 \\
TiO & 3 & 3 & $\mathbf{1}$ & 0 \\
OBC-TC2 & $\mathbf{2}$ & $\mathbf{1}$ & $\mathbf{0}$ & $\mathbf{0}$ \\
OBC-TC4 & $\mathbf{1}$ & $\mathbf{0}$ & $\mathbf{0}$ & $\mathbf{0}$ \\
OBC-TC6 & $\mathbf{1}$ & 0 & 0 & 0 \\
IHC-TC2 & 1 & 0 & 0 & 0 \\
IHC-TC4 & 1 & 0 & 0 \\
IHC-TC6 & 1 & 0 & 0 \\
\hline
\end{tabular}

0—No change; 1—Very slight effect; 2—Effect; 3—Light effect; 4—Definite effect; 5—Bad effect.

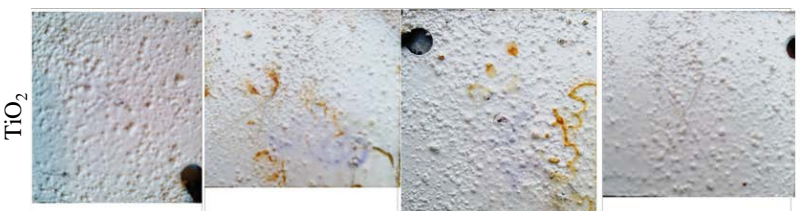

Original 2\% Sodium Chloride 2\% Sulphuric Acid 2\% Sodium Carbonate

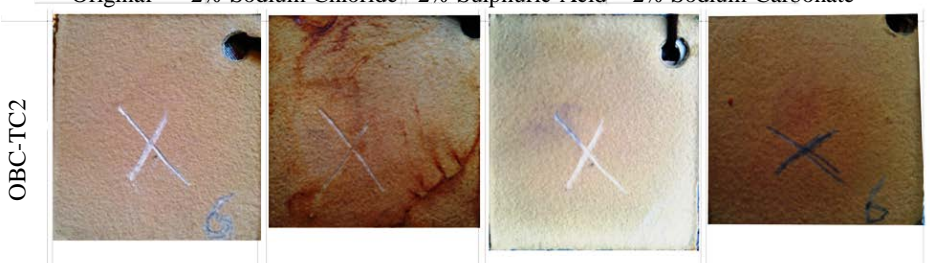

Original

2\% Sodium Chloride 2\% Sulphuric Acid 2\% Sodium Carbonate

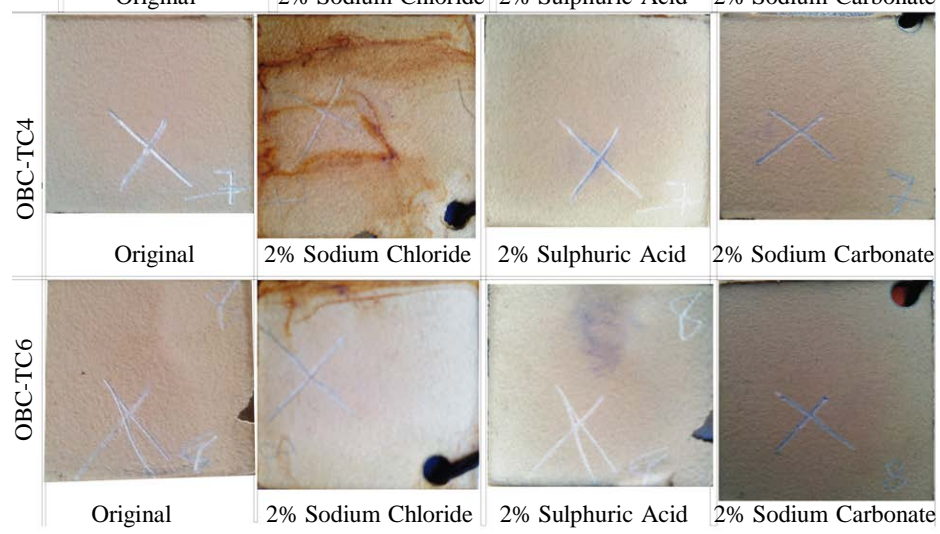

Figure 10. Pictures of media resistance test on paint film samples. 
of paint films. The stability of paint samples formulated using the core-shell pigments in $\mathrm{NaCl}$ solution means that the paints can be applied where high durability against corrosive environment is required.

\section{Conclusions}

Alkyd paint samples have been prepared using core-shell extender pigments prepared from Obowo, and IhitteUboma local clays. Paint samples formulated using $\mathrm{TiO}_{2}$ served as the reference paint and had the least viscosity value among the alkyd paint samples studied. The alkyd paint samples formulated using the core-shell pigments generally had low specific gravity, an indication that more of the core-shell pigments can be incorporated into the alkyd paints with considerable cost savings. The film thicknesses of the paint samples are in the range that places the paint samples as anticorrosive paints. The core-shell extender pigment formulated paint samples were observed to exhibit the best dust-free, tack-free, and through dry times. The adhesion properties of the paint samples are generally good which shows that they can withstand abrasive and corrosive agents. The core-shell extender pigments formulated paint samples exhibited moderate settling tendencies.

The alkyd dry film samples exhibited no chalking tendency, and mildew formation. The formulated paint samples shaded their colours on exposure to rain and sunlight, with only $\mathrm{TiO}_{2}$ paint formulation exhibiting rust. The formulated paint samples generally performed well in distilled water, $2 \% \mathrm{Na}_{2} \mathrm{CO}_{3}$, and $2 \% \mathrm{H}_{2} \mathrm{SO}_{4}$. The present study has demonstrated the utility of core-shell extender pigments from Obowo, and Ihitte-Uboma clays in formulating alkyd paints. The expectation is that this core-shell extender pigments should find utilizations in the surface coatings industry which will help to reduce the over dependence on imported extender pigments, thereby saving scare resource, spent on importation.

\section{References}

[1] PCI (Paint and Coating Industry) (2005) A Comprehensive Understanding of “ $\mathrm{TiO}_{2}$ Pigment Durability". http://www.pcimag.com/articles/a-comprehensive-understanding-of-tio2-pigment-durability

[2] Ahmed, N.M. and Mohamed, H.A. (2011) Performance of Phosphate-Alumina Pigments in Waterborne Paints for Protection of Cold-Rolled Steel. Journal of Coating Technology Research, 8, 201-210. http://dx.doi.org/10.1007/s11998-010-9288-8

[3] Sudipta, G.D., Bharath, P. and Arindam, R. (2011) Rayleigh Like Scattering from Silica-Titania Core-Shell Particles and Their Application in Protection against Harmful Ultraviolet Rays. Bulletin of Materials Science, 34, $199-206$. http://dx.doi.org/10.1007/s12034-011-0077-5

[4] Iler, R.K. (1959) Product Comprising a Skin of Dense, Hydrated Amourphous Silica Bound upon a Core of Another Solid Material and Process of Making Same. US Patent No. 2885366.

[5] Caruso, F., Susha, A., Giersig, M. and Mohwald, H. (1999) Magnetic Core-Shell Particles: Preparation of Magnetite Multilayers on Polymer Latex Microspheres. Advanced Materials, 11, 950-953. http://dx.doi.org/10.1002/(SICI)1521-4095(199908)11:11<950::AID-ADMA950>3.0.CO;2-T

[6] Caruso, R.A., Susha, A. and Caruso, F. (2001) Multilayered Titania, Silica, and Laponite Nanoparticle Coatings on Polystyrene Colloidal Templates and Resulting Inorganic Hollow Spheres. Chemistry of Materials, 13, 400-409. http://dx.doi.org/10.1021/cm001175a

[7] Nakamura, H., Ishii, M., Tsukigase, A., Harada, M. and Nakano, H. (2005) Close-Packed Colloidal Crystalline Arrays Composed of Polystyrene Latex Coated with Titania Nanosheets. Langmuir, 21, 8918-8922. http://dx.doi.org/10.1021/la050805q

[8] Nakamura, H., Ishii, M., Tsukigase, A., Harada, M. and Nakano, H. (2006) Close-Packed Colloidal Crystalline Arrays Composed of Silica Spheres Coated with Titania. Langmuir, 22, 1268-1272. http://dx.doi.org/10.1021/la052034w

[9] Holgado, M., Cintas, A., Ibisate, M., Serna, C.J., López, C. and Meseguer, F. (2000) Three-Dimensional Arrays Formed by Monodisperse $\mathrm{TiO}_{2}$ Coated on $\mathrm{SiO}_{2}$ Spheres. Journal of Colloid Interface Science, 229, 6-11. http://dx.doi.org/10.1006/jcis.2000.6973

[10] Guo, C.W., Cao, Y., Xie, S.H., Dai, W.L. and Fan, K.N. (2003) Fabrication of Mesoporous Core-Shell Structured Titania Microspheres with Hollow Interiors. Chemical Communications, 6, 700-701. http://dx.doi.org/10.1039/b212845d

[11] Kim, K.D., Bae, H.J. and Kim, H.T. (2003) Synthesis and Characterization of Titania-Coated Silica Fine Particles by Semi-Batch Process. Colloids and Surfaces A: Physicochemical and Engineering Aspects, 224, 119-126. http://dx.doi.org/10.1016/s0927-7757(03)00252-8

[12] Liu, L., Dong, P., Liu, R., Zhou, Q., Wang, X., Yi, G. and Cheng, B. (2005) Preparation and Self-Assembly of Uniform $\mathrm{TiO}_{2} / \mathrm{SiO}_{2}$ Composite Submicrospheres. Journal of Colloid Interface Science, 288, 1-5. 
http://dx.doi.org/10.1016/j.jcis.2004.11.048

[13] El-Toni, A.M., Yin, S. and Sato, T. (2006) Control of Silica Shell Thickness and Microporosity of Titania-Silica CoreShell Type Nanoparticles to Depress the Photocatalytic Activity of Titania. Journal of Colloid Interface Science, 300, 123-130. http://dx.doi.org/10.1016/j.jcis.2006.03.073

[14] Lim, S.H., Phonthammachai, N., Pramana, S.S. and White, T.J. (2008) Simple Route to Monodispersed Silica-Titania Core-Shell Photocatalysts. Langmuir, 24, 6226-6231. http://dx.doi.org/10.1021/la703899j

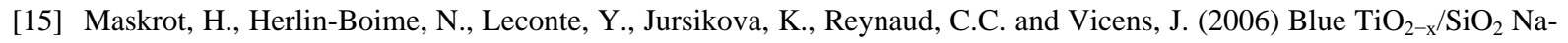
noparticles by Laser Pyrolysis. Journal of Nanoparticle Research, 8, 351-360. http://dx.doi.org/10.1007/s11051-005-9016-y

[16] Wilhelm, P. and Stephen, D. (2006) On-Line Tracking of the Coating of Nanoscaled Silica with Titania Nanoparticles via Zeta-Potential Measurements. Journal of Colloid Interface Science, 293, 88-92. http://dx.doi.org/10.1016/j.jcis.2005.06.047

[17] Hu, Y.J., Li, C.Z., Gu, F. and Zhao, Y. (2007) Facile Flame Synthesis and Photoluminescent Properties of Core/Shell $\mathrm{TiO}_{2} / \mathrm{SiO}_{2}$ Nanoparticles. Journal of Alloy Compounds, 432, L5-L9. http://dx.doi.org/10.1016/j.jallcom.2006.05.134

[18] Pérez, M., García, M., del Amo, B., Blustein, G. and Stupak, M. (2003) Core-Shell Pigments in Antifouling Paints. Surface Coatings International Part B: Coatings Transactions, 86, 259-262. http://dx.doi.org/10.1007/bf02699497

[19] Ahmed, N.M. and Selim, M.M. (2010) Tailored Ferrites-Kaolin Anticorrosive Hybrid Pigments in Solvent-Based Paints for Protection of Cold-Rolled Steel. Pigment and Resin Technology, 39, 101-111. http://dx.doi.org/10.1108/03699421011028699

[20] Ahmed, N.M., Abdel-Fatah, H.T.M. and Youssef, E.A. (2012) Corrosion Studies on Tailored Zn•Co Aluminate/Kaolin Core-Shell Pigments in Alkyd Based Paints. Progress in Organic Coatings, 73, 76-87. http://dx.doi.org/10.1016/j.porgcoat.2011.09.003

[21] Ahmed, N.M. and Selim, M.M. (2010) Modified Properties of Egyptian Kaolin-Phosphate Core-Shell Pigments in Solvent-Based Paints for Protection of Cold-Rolled Steel Surfaces. Pigment and Resin Technology, 39, 15-26. http://dx.doi.org/10.1108/03699421011009555

[22] Ewulonu, C.M., Igwe, I.O. and Onyeagoro, G.N. (2016) Synthesis and Characterization of Local Clay-Titanium Dioxide Core-Shell Extender Pigments. Journal of Coatings Technology and Research, Accepted. http://dx.doi.org/10.1007/s11998-016-9786-4

[23] Koleske, J.V. (1995) Driers and Metailc Soaps. In: Koleske, J.V., Ed., Paint and Coating Testing Manual: Fourteenth Edition of the Gardner-Sward Handbook, ASTM, Philadelphia, 33-52.

[24] Weaver, C.E. (1976) The Nature of $\mathrm{TiO}_{2}$ in Kaolinite. Clays and Clay Minerals, 24, 215-218. http://dx.doi.org/10.1346/CCMN.1976.0240501

[25] Imerys (2009) Saving $\mathrm{TiO}_{2}$ in Semi-Gloss Emulsion Paints with Supreme. Imerys World Minerals Publication. www.imerys-perfmins.com

[26] Tiwari, S. and Saxena, M. (1999) Use of Fly Ash in High Performance Industrial Coatings. British Corrosion Journal, 34, 184-191. http://dx.doi.org/10.1179/000705999101500824

[27] Osabor, V.N., Okafor, P.C., Ibe, K.A. and Ayi, A.A. (2009) Characterization of Clays in Odukpani, South Eastern, Nigeria. African Journal of Pure and Applied Chemistry, 3, 79-85.

[28] Morgans, W.M. (1990) Outlines of Paint Technology. Edward Arnold, London.

[29] Henton, L.E. (1981) Determination of Volume Solids of Paints and Coatings. Engineering Experiment Station, Georgia Institute of Technology, Atlanta.

[30] Nylen, P. and Suderland, E. (1965) Modern Surface Coatings. Interscience, London.

[31] Payne, H.F. (1954) Organic Coating Technology: Volume 1, Oils, Resins, Varnishes, and Polymers. Chapman \& Hall, New York, London.

[32] Kezaiah, A.C. and Ogbennaya, I.I. (2012) Studies on the Use of an Industrial Waste Clay in Alkyd Paint Formulations. International Journal of Academic Research, 4, 306-313.

[33] Tan Tian Aik, D. (1995) Durability and $\mathrm{TiO}_{2}$ Pigments. 1995 Paintindia Annual, 84-93.

[34] Muralidharan, N.M., Unnikrishnan, K.G., Unnikrishnan, M. and Nair, C.S.B. (1981) Utilization of Rubber Seed Oil and Karinnota Oil for the Preparation of Air Drying Oil Modified Alkyd Resin. Paintindia, 31, 5-9. 